\title{
Angler-problemet - endnu engang
}

af $H . V$. Gregersen

Ordene »England og »englændere« har udgangspunkt $i$ ordene »Angel« og »anglere«. Det er også en kendsgerning, at anglerne var en af de grupper, som i folkevandringstiden var med til at danne det engelske folk. Men hvor kom anglerne fra? Om dette spørgsmål hersker der stor uklarhed. Dr.phil. H.V. Gregersen argumenterer her for, at anglerne i 400-årene kom til England fra et Angler-rige i Sønderjylland mellem Olmersdiget og Ejderen, måske presset vestover af de fremstormende danere - og at andre af anglerfolkene på et tidligere tidspunkt var draget fra det nordlige Angler-rige til Elbe-Saale-området i Thüringen.

\section{Indledning}

Kom anglerne i England fra halvøen Angel (og nærmeste omegn), eller kom de fra et område ved Elben og dens biflod Saale i det østlige Thüringen? Det er $\mathrm{i}$ al korthed dette spørgsmål, der kaldes angler-problemet, og alle forskere, der har beskæftiget sig med anglernes herkomst, har følgelig måttet tage stilling hertil og har valgt side.

De to opfattelser af, hvor anglerne i England kom fra, hviler på tre hovedkilder, deraf to klassiske, nemlig den romerske historiker Cornelius Tacitus (omkring år 100) og den alexandrinske geograf Klaudios Ptolemaios (efter år 150), samt som det tredje den angel-saxiske kirkehistoriker Beda »den Erværdige«, hvis værk stammer fra 731. Dertil kommer forskellige sekundære kilder, hovedsageligt fra Englands middelalder, men til sådanne må også visse klassiske forfattere regnes (f.eks. Prokopios) og et håndskrift fra Karl den Stores tid, "Lex Angliorum et Werinorum, hoc est Thuringorum«.

Som man vil have bemærket, er hovedkilderne alt andet end samtidige med anglernes indvandring til England omkring 450. De to fra antikken er langt ældre, og Bedas kirkehistorie er næsten 300 år yngre end denne begivenhed.

På denne baggrund kan det naturligvis synes voyeligt at forsøge sig med en historisk behandling af et emne som angler-problemet. Alligevel må det på grund af den nære tilknytning til Sønderjyllands oldhistorie være nærliggende at beskæftige sig med det i Sønderjyske Årbøger, og det er da også tidligere sket.

I 1951 fremlagde Anders Bjerrum her sin afhandling, "Anglernes hjemstavn «, der stadig er læseværdig, ${ }^{1}$ og den tilføjede litteraturfortegnelse gør den til et godt udgangspunkt for enhver, der ønsker at sætte sig ind i anglerproblemet. I den herværende fremstilling henvises der derfor generelt til Bjer- 
rums afhandling, mens der i noterne gøres opmærksom på senere tilkommen litteratur.

Bjerrums afhandling blev året efter - også i Sønderjyske Årbøger - fulgt op af en protest fra Gudmund Schütte. Som titlen på dette indlæg siger, "Anglerne - det evige stridsæmne«, er der fra Schüttes side lagt op til et verbalt slagsmål, og efter læsningen af de to afhandlinger kan ingen være i tvivl om de to forfatteres modstridende opfattelse af, hvor anglerne i England kom fra.

Noget af det skyts, som Schütte kører frem med, indgår også i de efterfølgende betragtninger, der naturligvis kun kan være af hypotetisk natur, men - som Novalis har skrevet - „Hypothesen sind wie Netze; nur Der wird fangen, der auswirft«.

\section{Kildematerialets udsagn}

"De klassiske hjemmelsmænd for anglernes hjemstavn« (Schüttes formulering) er som næunt $i$ indledningen Tacitus og Ptolemaios.

Tacitus's omtale af anglerne findes i hans "Germania«, hvor han efter at have nævnt en række folkestammer fra Rhinen og op mod Elben - og sidst blandt disse langobarderne - oplyser, at syv folkestammer er fælles om at dyrke Nerthus. Hans fremstilling lyder således: "Dernæst har Reudigni, Aviones, Anglii, Varini, Eudoses, Suardones og Nuithones floder og skove til værn. Hos disse folk er der ikke noget at mærke sig ud over, at de i fællesskab dyrker Nerthus, det vil sige: Moder Jord, og de tror, at hun griber ind $\mathrm{i}$ menneskenes færden og på en vogn kører omkring mellem folkene. På en $ø \mathrm{i}$ Oceanet findes der en hellig lund og $i$ denne en indviet vogn, der dækkes af et tæppe. Præsten er den eneste, der har lov til at berøre den. Han mærker, når gudinden er til stede $\mathrm{i}$ sin helligdom, og - mens hun kører af sted på sin vogn, som trækkes af køer - ledsager han hende under dyb ærefrygt. Da er der glade dage, og der holdes fest på de steder, hun hædrer med sit besøg. Man går ikke $\mathrm{i}$ krig og griber ikke til våben; alt jern er gemt hen under lås og lukke; fred og ro hersker, indtil gudinden har fået nok af at færdes mellem menneskenes børn, og præsten derfor bringer hende tilbage til det hellige sted. Derefter bliver vognen og tæpperne, og om man vil tro det, selve guddommen tvættet i en skjult liggende sø. Herved bistår trælle, som søen straks opsluger. Derfra hidrører den lønlige rædsel og den fromme uvidenhed om, hvad dét er, som kun dødsviede ser«.

Af de syv navne på folkestammer kendes kun anglerne og varnerne fra andre kilder. Varnerne er åbenbart et nabofolk til anglerne. De har ikke 
noget med Varnæs at gøre, men måske snarere med flodnavnet Warnow (med Warnemünde), og de antages derfor almindeligvis at have boet $\mathrm{i}$ det østlige Holsten og det vestlige Mecklenburg. Navnene på nogle af de andre Nerthusfolk er' muligvis stærkt forvanskede i gengivelsen af Tacitus's tekst. Således anser flere forskere Eudoses for en betegnelse for jyderne, men ellers må tolkningsforsøgene med hensyn til de andre navne nok anses for endog meget usikre.

Anglerne er de eneste af de syv Nerthus-dyrkende folkeslag hos Tacitus, som også Ptolemaios kender. Hans udsagn lyder således: "Af de $i$ landets indre boende folk er de største: Sueboi-Angiloi, som bor øst for Langobardoi og strækker sig mod nord indtil den midterste del af floden Albis (d.e. Elben), Sueboi-Semnones, som strækker sig fra den nævnte del af Albis mod øst til floden Suebos (d.e. Oder), og Burguntai, som ejer landet derfra og over til Uistula (d.e. Wisla, Weichsel)«.

Der kan ikke være tvivl om, at de nævnte folkeslag af Ptolemaios bliver placeret længere mod øst end hos Tacitus, for anglerfolkets vedkommende i egnen ved Elbens midterste løb. På den Jyske Halvø har han anbragt syv folkestammer: "Selve halvøen bebos oven for (d.v.s. nord for) sachserne af Sigulones mod vest, derefter Sabalingioi, derefter Kobandoi, oven for disse Chaloi og oven for disse igen mod vest Fundusioi og mod øst Charudes, og øverst af alle Kimbroi«.

Ingen af de næunte stammer kan identificeres med de Nerthus-dyrkende folkeslag hos Tacitus (selv om enkelte har foreslået, at Fundusioi kan være en fejlskrivning for "Eudusioi«, hos Tacitus: Eudoses). Charudes og Kimbroi vil de fleste derimod nikke genkendende til som en gengivelse af harderne $i$ Hardsyssel og kimbrerne i Himmerland. Men om Sabalingioi lader sig forbinde med Salling, er nok noget tvivlsomt.

Mens der hos Ptolemaios ikke er plads til anglerne på den Jyske Halvø, er den tredje af hovedvidnerne om deres oprindelige hjemstavn, den angel-saxiske kirkehistoriker Beda, ikke i tvivl herom, idet han om Britanniens erobrere beretter følgende:

"De kom fra tre tapre germanske stammer, nemlig saxerne, anglerne og jyderne. Af jydernes stamme er beboerne fra Kent og Wight (Cantuarii et Uictuarii), og fra det, som endnu kaldes jydernes nation (Jutarum natio), liggende over for øen Wight $\mathrm{i}$ vestsaxernes provins. Fra saxerne, d.v.s. fra den egn, som nu kaldes gammelsaxernes, kom østsaxerne, midtsaxerne og vestsaxerne (d.v.s. beboerne af de gamle kongeriger Wessex, Middlesex og Essex). Endelig har østanglerne, midtanglerne og mercierne (d.v.s. beboerne af East Anglia, Middle Anglia og Mercia [jvf. tysk: Mark, grænseprovins]) og hele northumbrernes stamme, d.v.s. de folk, der bor nord for floden Humber, 
og de øvrige angelske folk deres udspring fra anglerne, d.v.s. fra det fædreland, som kaldes Angel, og som siges at have ligget øde mellem jydernes og saxernes provinser fra hin tid til nu (sidste sætning efter »d.v.s.« lyder på Bedas latinske skriftsprog: " de illa patria, quae Angulus dicitur et ab eo tempore usque hodie manere desertus inter provincias Jutarum et Saxonum perhibetur«). Alle senere angel-saxiske krøniker står på en eller anden måde i gæld til Beda, og de skal derfor ikke refereres her.

Hvad der i øvrigt findes af kildemateriale, er sparsomt og usikkert. En smule betydning har dog oplysningerne hos den østromerske historiker Prokopios (død 562), idet han om Britanniens erobring udtaler: "Øen Brittia rummer tre folkeslag med hver sin konge, nemlig Angiloi, Phrissones og Brittones«. Prokop bliver derved den eneste, der også nævner friserne blandt Englands beboere, men - hvad der kan synes ejendommeligt - han nævner ikke saxerne blandt indbyggerne i England.

Bemærkelsesværdig er desuden en lov fra Karl den Stores tid. Den har påkaldt sig interesse, fordi den kaldes Lex Angliorum et Werinorum, hoc est Thuringorum (»anglernes og varnernes, d.v.s. thüringernes lov«). Ligesom hos Tacitus nævnes de to folkeslag altså også her i sammenhæng.

Det fremlagte kildemateriale viser, at der helt tydeligt er tale om to modsatte udsagn om, hvor anglernes hjemstavn skal søges, og det har naturligvis voldt store vanskeligheder for alle de mange lærde og særdeles indsigtsfulde forskere, der har beskæftiget sig med angler-problemet. Om dem alle gælder det, at de har arbejdet ud fra en bestemt forhåndsopfattelse, ud fra en i forvejen udtænkt arbejdshypotese; det kan vel derfor næppe undre, at det også gælder den herværende fremstilling.

\section{Tolkning af kildematerialet}

\section{Udsagn, der peger på landskabet Angel}

Hos Tacitus er der især to forhold, som man bør lægge mærke til, nemlig at han - efter at have omtalt langobarderne (der almindeligvis menes at have boet ved Elbens nedre løb, jvf. bynavnet Bardowiek) - nævner anglerne som en af de syv Nerthus-dyrkende folkestammer, og om disse fremhæver, at de har en hellig lund "på en $ø$ i Oceanet«. Ud fra disse to oplysninger kan det vel ikke være urimeligt at opfatte de nævnte folkestammer som bosatte på den Jyske Halvø. Anglerne kan derfor udmærket have været hjemmehørende i Angel og nærmeste omegn.

På Tacitus's tid var »Oceanet« alt det vand, der efter den tids verdensbillede omgav det faste land. Nordsøen var derfor en naturlig del af »Oceanet«, og 
det var først, da man i senere århundreder var blevet klar over, at Østersøen var en indbugtning fra "Oceanet«, at man almindeligvis foretrak at betegne dette hav med ordet "Mare«, Mare Balticum. ${ }^{2}$

Tacitus's oplysninger om beliggenheden ved „Oceanet« kan således med god ret opfattes som samstemmende med Bedas klare udsagn om, at anglerne i England var kommet fra landskabet Angel i Sydslesvig, og det ikke mindst, når man antager, at anglerne har beboet hele det nuværende Sydslesvig (og desuden - som vi skal se - den sydøstlige del af Nordslesvig). Dertil kommer, at Tacitus's ejendommelige skildring af den såkaldte Nerthus-kult ligeledes synes at pege hen på forhold i det nordiske, idet Nerthus utvivlsomt er en
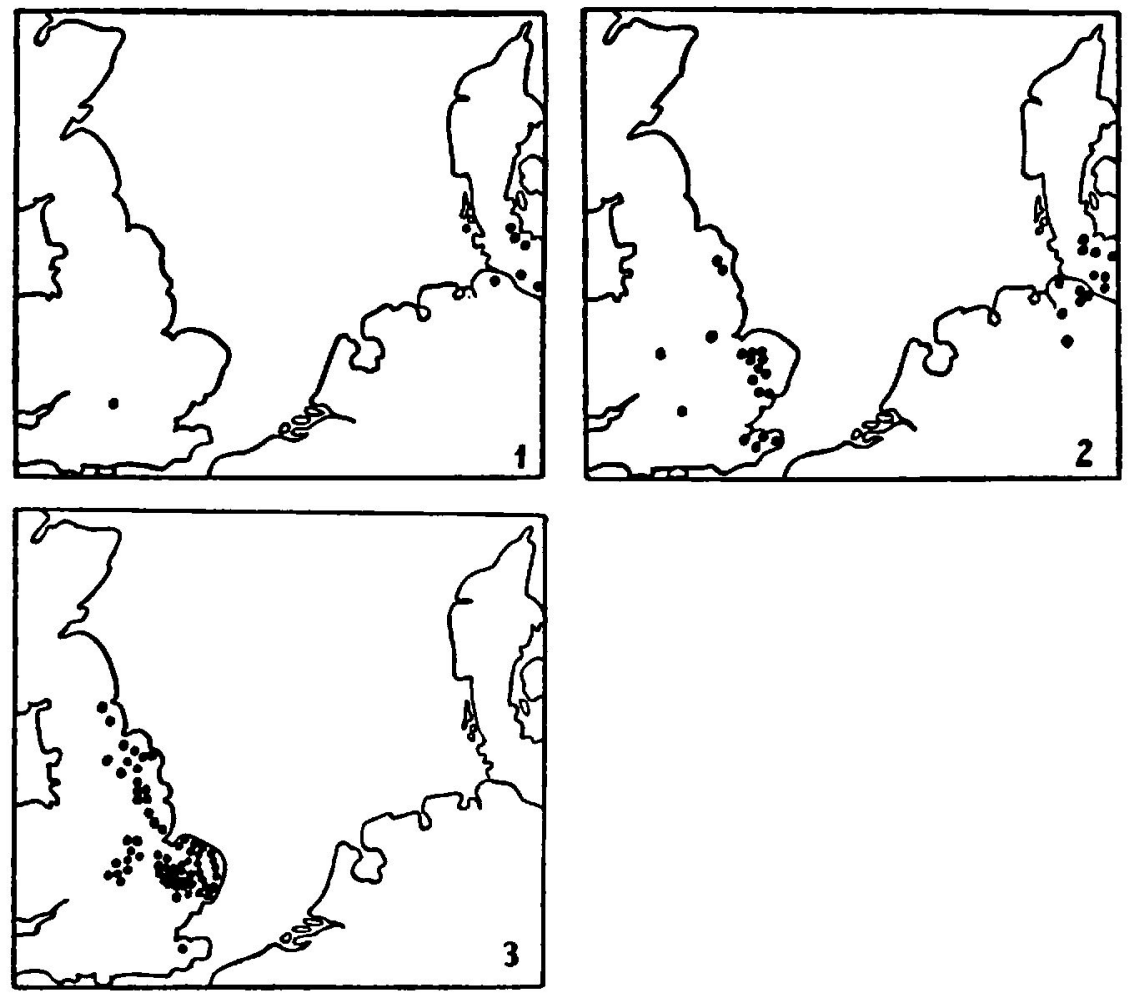

I afhandlingen "Zur Frage nach der Urheimat der Angeln" (Zeitschrift der Ges. f. Schleswig-Holsteinische Geschichte, 1943) har H.Jankuhn bragt disse kort over fund af bøjlenåle fra tidsrummet 400-600. Kortene 1-3 viser hhv. aldste, midterste og yngste type, og de virker ved forste ojekast som en serie dokumentariske illustrationer af, hvordan invasionen til England forløb. Jahnkuhn tolker fundene som bevis på, at sachserne og anglerne har forladt hjemstavnen på fastlandet $i$ den midterste periode for at rejse til England. Hvor besnarende end kortene ser ud, har denne form for bevisforelse dog ikke fundet tilslutning. Indvandringen af anglere til England lader sig ikke pdvise ved hjalp af arkaologien. 
omskrivning af det nordiske gudenavn Njordr. Om dyrkelsen af denne gud/ gudinde findes der ingen spor syd for Ejderen, men derimod adskillige vidnesbyrd i Norden.

Hos Snorre, hjemmehørende i Norges middelalder, hedder $\operatorname{det}^{3}{ }^{3}$ "Mens Njord var hos vanerne, havde han sin søster til hustru, thi det var lov hos dem; deres børn var Frej og Freja«. Tacitus kalder Nerthus for "Moder Jord» til trods for, at den latinske endelse -us er hankøn, og det er da naturligt at anse denne form for gudsdyrkelse for en gammel frugtbarhedskult. Hans skildring af guddommens køretur i en indviet vogn (jvf. Dejbjerg-vognen) og velsignelsen af markerne, så at der kunne komme grøde i jorden, samt omtalen af freden på jorden er træk, af hvilke nogle ikke blot genfindes hos Snorre, men også i senere tradition.

Det skal indrømmes, at der er uendelig langt fra oldtidens Tacitus til middelalderens Snorre (selv om Dejbjerg-vognen tidsmæssigt ligger imellem), og der er endnu længere til det gamle landsbysamfunds riden eller køren "sommer $\mathrm{i}$ by« og til et i Sønderjylland udbredt sagn, der lader en »frue ( jvf. Freja) køre vild og drukne sammen med sin kusk i en »Fruesø« eller »Fruepyt«, eller lader et brudepar omkomme ved at køre ud i en "Brudesø sjøv $\aleph^{4}$ eller - som det nutildags hedder i Slesvig by - »Brautsee«. Et minde om den »fred og ro«, der ifølge Tacitus herskede, mens guddommen var blandt menneskenes børn, er måske overleveret i Saxos gengivelse af sagnet om Frode Fredegod.

Hvis det virkelig skulle være tilfældet, at de omtalte sagn er mindelser om en fjern fortids frugtbarhedskult, har vi her atter engang et vidnesbyrd om den kontinuitet, der så ofte spores i vort folks historiske udvikling, ${ }^{5}$ og dertil et vidnesbyrd om, at anglernes efterkommere endnu lever $i$ bedste velgående, ikke blot i England, men også inden for det sønderjyske område. Den sidste påstand - andet kan det jo ifølge sagens natur ikke blive - vil vi senere vende tilbage til.

\section{Udsagn, der peger på Elbe-Saale-området}

Det ville være i strid med alle principper for en videnskabelig fremstilling, hvis man, efter at have tilsluttet sig den opfattelse, at anglerne var hjemmehørende i landskabet Angel (med omegn), ville nøjes med at afvise det kildemateriale, der peger på, at anglernes oprindelige hjemstavn var egnen omkring Elben og dens biflod Saale i Sachsen-Anhalt og Thüringen.

Det går ikke an uden videre med hensyn til Ptolemaios at hævde, at han har taget fejl adskillige gange, bl.a. ved at henvise til, at hans anbringelse af langobarderne på »et splittergalt sted« ved Rhinen (G. Schütte) gør ham utroværdig. Ikke mindst må en sådan påstand være betænkelig, når der i 
forvejen er givet gode grunde for, at Ptolemaios's placering af anglerne med nogenlunde sikkerhed kan forstås ud fra det på hans tid gældende verdensbillede. Det skal ovenikøbet være muligt også at læse Tacitus's oplysninger ud fra denne forudsatning, således at der bliver overensstemmelse mellem de to antikke forfattere (Lauritz Weibull i Scandia 1934).

Det går ejheller an at påstå, at det omtalte lovhåndskrift slet ikke vedrører Thüringen, men derimod et nederlandsk område syd for Maas ved navn Doringen, også kaldt Thoringia (senere kendt som Toxania). Hvorfor skulle man dog på Karl den Stores tid udfærdige en særlig lov for et lille område inden for hans eget rige? Det er derfor nok mere rimeligt at antage, at loven skulle vare gældende i Thüringen, der siden 531 var under frankisk herredømme. Det var et østligt grænseområde med egen lokalforvaltning, og det modtog ikke mindst på Karl den Stores tid en del tilflytning fra andre egne af hans rige. Måske forklarer dette et navn som Fresonofeld, åbenbart opkaldt efter frisiske indvandrere.

Visse forskeres forsøg på at løse angler-problemet ved helt enkelt at foreslå, at der er tale om to forskellige folkeslag, der blot har haft en vis navnelighed og derfor begge er blevet kaldt anglere, er nok en lidt for letbenet måde at slippe uden om vanskelighederne på. Ud fra det foreliggende kildemateriales svage antydninger om anglernes geografiske placering må Ptolemaios stå til troende lige så vel som Tacitus. Der er derfor ingen vej udenom: der har også boet anglere i Elbe-Saale-området.

Deres bosættelse her kan imidlertid uden større vanskelighed opfattes som resultatet af en folkevandring. Ligesom så mange andre folkevandringsstammer kan også nogle af anglerne sammen med deres naboer varnerne fra deres hjemstavn på den Jyske Halvø være søgt sydpå mod solens lande, og det må være sket ved den tid, da mange nordiske oldtidsbønder som følge af en klimaændring $^{6}$ måtte opgive at dyrke deres hjemlige jord og måtte vandre mod syd for at overleve, nemlig engang i tiden efter Kristi fødsel.

Denne opfattelse af begivenhedsforløbet må ovenikøbet anses for rimeligere end tanken om, at et "landkrabbe«-folk fra det indre af Nordtyskland skulle være vandret mod nord-vest ud til Nordsø-kysten for derefter i 400-tallet at sætte over til den af romerne forladte ø Britannien.

\section{Excurs: Danerne og stednavnene på -lev og på -leben}

En art parallel til anglernes bosættelse på den frugtbare løss-jord ved Elben og Saale (og om man vil en bekræftelse af hypotesen om en stedfunden folkevandring hertil) har man i forekomsten af de mange stednavne med endelsen -leben i Sachsen-Anhalt og Thüringen.? Kendt er Martin Luthers fødeby Eisleben, og ved Saale findes f.eks. et Alsleben. Selv om nogle sprogfor- 
skere - blandt dem Anders Bjerrum og Kristian Hald - har gjort opmærksom på, at navne på -leben udmærket kan være udviklet selvstændigt $\mathrm{i}$ forhold til den danske stednavneendelse -lev, er det dog nok mest almindeligt at opfatte lev-bebyggelsen på dette strøg som et minde om, at der også blandt danerne har fundet en folkevandring sted til disse egne. Bent Søndergaards påvisning af, at hvert tiende af disse stednavne har et personnavn som forled, der beviseligt genfindes i danske lev-navne, bestyrker denne opfattelse.

Det karakteristiske ved udbredelsen af lev-navnene er netop, at de findes udbredt overalt inden for det Danske Riges historiske område (med undtagelse af Blekinge og Bornholm). ${ }^{8}$ Kun få eksempler findes hinsides grænsen til Sverige. Lev-byernes forled er personnavne fra før-kristelig tid, og da de er kraftigst udbredte i egnene på begge sider af Øresund - altså inden for det område, der tillægges danerne - er deres udbredelse på Fyn og i Jylland af H.V. Clausen blevet anset for et vidnesbyrd om danernes erobring af hele Danmark.9

Når det oprindelige jyske stammeområde langs med vestkysten ikke har så mange lev-byer som det øvrige Jylland, kan det måske skyldes, at jydernes forening med danerne er foregået efter en aftale, hvorimod de store offerfund fra jernalderen - Vimose og Kragehul på Fyn, Thorsbjerg i Angel, Nydam i Sundeved, Ejsbøl ved Haderslev og Illerup ved Skanderborg - tyder på, at danerne er trængt erobrende frem til disse egne, til Fyn og til den Jyske Halvøs østlige egne.

Et af argumenterne for, at erobrerfolket kom østfra, er den - nu tabte Nydambåd af fyrretræ. Den må stamme fra den Skandinaviske Halvø, hvor fyrren på den tid var et skovtræ. Da efterleddet -lev betyder: whvad der efterlades eller overlades« (underforstået: af jordegods), er det nærliggende at antage, at det er erobrerfolkets stormænd, der findes næunt $i$ forleddets personnavne. ${ }^{10}$

\section{Olmersdiget som bevis for et Angler-rige}

Det er de i årene 1963-1972 foretagne arkæologiske undersøgelser ved Vilhelm la Cour og Hans Neumann af Olmersdiget, ${ }^{11}$ der er baggrunden for de her fremsatte betragtninger om anglernes herkomst.

Olmersdiget er nemlig ved sin opbygning og udstrækning næst efter Danevirke-voldene den betydeligste og geografisk set mest fuldkomne spærring af den Jyske Halvø, der kendes. »Diget ( (smlgn. eng. dyke, ditch; tysk Deich, Teich) har et sådant omfang, at kun et folkeslag under en fast og samlet ledelse har kunnet gennemføre et anlæg af den art.

Olmersdiget strækker sig fra Aabenraa-skovenes vestlige udløbere $\mathrm{i}$ det derværende stærkt bakkede moræne-terræn frem til Vidå-systemets brede 
vandføring i det sumpede terræn vest for Tinglev, og det har været et imponerende anlæg med en dyb og bred voldgrav og tre rækker kraftige palisader, bestående af tykke egestammer, der visse steder har været hugget i firkant og været sammenstillet som en tæt mur. Ifølge en C14-datering stammer anlægget fra ca. 200 e. Kr.

Således som Olmersdiget findes placeret $\mathrm{i}$ terrænet, tyder alt på, at det er bygget som et værn mod angribere nordfra, og det har først og fremmest været Hærvejens gamle nord-sydgående færdselsstrøg ned gennem den Jyske Halvø, som det har været dette forsvarsvirkes opgave at skulle spærre for. ${ }^{12}$ Placeringen af bronzealderens gravhøje og oldtidsfund af forskellig art fortæller klart og umiskendeligt, hvor hine tiders hovedfærdselsstrøg gik, nemlig umiddelbart vest for den Baltiske Istids hovedstilstandslinje. Her i det forholdsvis jævne og sandede terræn med de smalle vandløb fandtes de færreste naturlige forhindringer for færdselen, og det er derfor netop her, Olmersdiget er anlagt som et tydeligt skel mellem to folkeslag, og hvis Bedas udsagn om, at anglerne kom fra "det fædreland, som kaldes Angel, og som siges at have ligget øde hen mellem jydernes og sachsernes provinser fra hin tid og til nu«, kan tages for fuldt pålydende, må det være anglerne, der med dette anlæg har søgt at værne deres land.

Jydernes bosættelsesområde antages nemlig at have strakt sig på begge sider af Kongeåen, oprindelig måske fra Skjern ås brede dal til strøget mellem Aabenraa-skovene og Vidåens udløb, ${ }^{13}$ med andre ord: sydpå til det skel, som Olmersdiget markerer.

Samme skel kan den dag i dag så nogenlunde opfattes som en dialektgrænse, idet folkesproget i den sydlige og sydøstlige del af det nuværende dansktalende Sønderjylland er kendetegnet ved den såkaldte "musikalske dobbeltakcent «. ${ }^{14}$ Denne særlige sprogklang kendes fra halvøen Løjt og derfra over til Aabenraa fjords sydlige sogne Felsted og Varnæs, samt ud over hele Sundeved og over til øen Als. Egnen nord for Flensborg fjord fra Gråsten til Bov har ligeledes samme sprogtone. Syd for vor landegrænse kendes den endnu fra Handved sogn, og der findes vidnesbyrd om, at angelboerne inden sprogskiftet til plattysk har haft samme dialekt. Derimod kendes den ikke længere mod vest i Uge og Tinglev sogne og ej heller hos de dansktalende i det sydslesvigske midterlands hedeegne. Alligevel er den nordlige afgrænsning af »den musikalske dobbeltakcent « $\mathrm{i}$ forhold til Olmersdiget så påfaldende, at man kan fremsætte den hypotese, at den er et minde om anglernes nordiske sprog. ${ }^{15}$

Ud fra disse betragtninger over udbredelsen af »den musikalske dobbeltakcent « $\mathrm{i}$ vor tid tør det antages, at jernalderens Angler-rige har strakt sig fra skovlandet omkring Aabenraa fjord og - længere vestpå - fra Olmersdiget sydpå ud over det sydøstlige Nordslesvig og ud over hele Sydslesvig (idet 


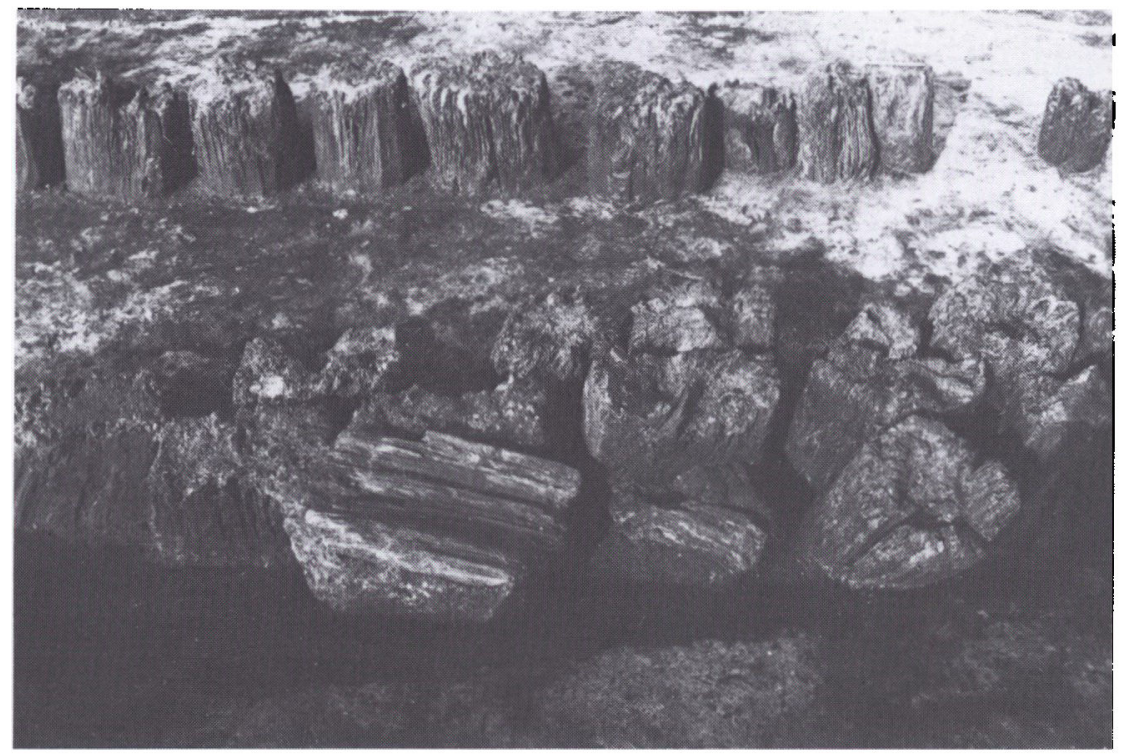

Udgravede palisader i Olmersdiget - màske Angler-rigets varn mod nord - ved Almstrup ost for Tinglev. $I$ vor ofte miljobevidste tid kan vi ved synet af digets solide palerakker nok anstille betragtninger over, om man $i$ oldtiden just har varet skånsom over for den gamle egeskov. Foto Hans Neumann 1972. Haderslev Museum.

friserne på den tid endnu ikke var indvandret til denne landsdels vestkyst). Som sydlig afgrænsning må det være mest naturligt at pege på ødemarksområdet på begge sider af Ejderen.

Alt $\mathrm{i}$ alt har Angler-riget således været af et ret beskedent omfang, selv om det er muligt, at det også har omfattet de syd-fynske øer. Ejendommeligt nok hører nemlig også Ærø, Langeland, Thurø og andre småøer med til det sproglige akcent-område.

En vag antydning af, at der har eksisteret et sådant rige, er muligvis givet i den ældre (angel-)saxiske litteratur, idet anglerne her ikke nævnes med folkenavn, hvilket ellers gerne er tilfældet, når der i ældre litteratur er tale om folkevandringsfolk. ${ }^{16}$ I det gamle epos Widsith tales der om landet »Ongle«, og hos Beda bruges - som tidligere anført - landsdelsbetegnelsen "Angulus«. Men i begge tilfælde kan disse navne naturligvis være udtryk for en art opprioritering af anglerne, svarende til, hvad der - som vi senere skal høre rent faktisk skete med anglerne i Britannien.

Olmersdiget lader sig som nævnt datere (omend med en vis usikkerhed) til tiden omkring år 200 e. Kr., og da anglernes udvandring til Britannien menes 
at have fundet sted omkring år 450, er der hermed givet en ydre tidsramme for eksistensen af et Angler-rige i Sønderjylland.

Det vil selvsagt være halsløs gerning at forsøge at udrede trådene for, hvad der er sket inden for de 200-300 år, et sådant rige må have eksisteret. Kun vage antydninger er mulige. Omtalen af anglerne i Elbe-Saale-området hos Ptolemaios (ca. 150 e. Kr.) kan - som ovenfor nævnt - tolkes derhen, at nogle af anglerne har været på vandring mod syd, længe før andre af dem sejlede over til Britannien.

Udvandringen i 400-årene svarer meget fint til pollen-analysernes udsagn om, at hidtil dyrket jord ved den tid blev overtaget af bøgeskoven, ${ }^{17}$ ligesom de store mose-offerfund fra 300-400-årene vidner om, at et angribende folk er trængt ind på anglernes enemærker. Alt tyder på, at de sejrende i disse kampe har været danerne, og at de har gjort sig til herrer over den restbefolkning, der ikke udvandrede til Britannien. Et varigt minde herom er de i området spredt forekommende stednavne med endelsen -lev. Det er navnene på danerstormænd, der findes i disse stednavnes forled!

Følgen af danernes overherredømme blev, at det danske folk og dermed et fælles Dansk Rige, der på den lille Jellingsten har fået navnet Danmark, skabtes ud af treklangen daner, jyder og angler. Den ældste datering af Danevirke vidner om, at denne proces var fuldbyrdet i 600-700-årene.

Folkenavnet TANI på den store Jelling-sten fra ca. 985 skal derfor retteligt oversættes »danskerne" (Harald Blåtand "gjorde danskerne kristne«).

\section{Det sproglige problem}

Det var Anders Bjerrums opfattelse af de sproglige forhold, der var hovedanliggendet med afhandlingen om Anglernes hjemstavn i Sønderjyske Årbøger 1951. Det stod ham nemlig helt klart, at anglerne - som formodede vestgermanere og derfor talende et sprog, der lå de tyske sachseres nært - ikke kunne være kommet fra det nuværende Sydslesvig, for alle gamle sproglige vidnesbyrd fra denne landsdel vidner om, at befolkningen her har talt nordgermansk, d.v.s. et nordisk sprog. Fremtrædende blandt disse vidnesbyrd er ikke mindst landsdelens stednavne, af hvilke de ældste går tilbage til folkevandringstiden. Efter disse betragtninger blev Bjerrums konklusion derfor: "Sproget i Sønderjylland var sandsynligvis - bortset fra de sydligste og sydvestligste egne (hvor holstenere og frisere var bosatte $\mathrm{i}$ middelalderen) - nordisk så tidlig som $\mathrm{i}$ folkevandringstiden og har rimeligvis aldrig været vestgermansk «.

Samtidig afviste Bjerrum de forsøg, der var gjort på at hævde, at anglerne i oldtidens England har talt et sprog, der lå midt imellem vestgermansk og nordgermansk. Han måtte ligeledes afvise en opfattelse, der gik ud på, at anglerne skulle have tilført det oldengelske sprog en del ord, som ellers ikke 
findes $\mathrm{i}$ vestgermansk. Med hensyn til sådanne eksempler mente Bjerrum, at »disse få gloser på ingen måde er tilstrækkelige til at konstituere et nært slægtskab mellem nordisk og den angelske afdeling af oldengelsk; på alle væsentlige punkter, f.eks. i henseende til bøjningsendelserne, er anglernes og saxernes sprog fuldstændig ens og nær beslægtet med oldfrisisk og oldsaxisk. Der er ingen vej udenom: Anglerne talte et vestgermansk sprog! «

For Bjerrum var det herefter klart: Anglerne i England kunne umuligt være kommet fra det sydslesvigske Angel og omegn, og folgelig fik hans afhandling det sigte at fremhæve alt det, der talte for, at anglerne i England havde deres oprindelige hjemstavn i Elbe-Saale-regionen. Det var med andre ord det sproglige kriterium, der var udslaggivende.

Spørgsmålet er så blot, om modsætningsforholdet mellem nordgermansktalende anglere i Angel og vestgermansktalende anglere i England ikke blot kun er tilsyneladende. Der kunne jo være tale om noget så simpelt som et sprogskifte!

Noget sådant er almindeligt kendt fra den vældige udvandring, der fra midten af 1800-tallet og op til 1914 fandt sted i Amerika. Hundredtusindvis af skandinaver og tyskere, der kom til det engelsktalende Nordamerika, opgav i løbet af en generation eller to deres oprindelige modersmål, og det samme var tilfældet med alle de mange italienere, der kom til Latinamerika.

Det er nemlig en simpel erfaringssag, at udvandrere, der taler et nærtbeslægtet sprog, hurtigt lærer flertalsbefolkningens sprog og efterhånden skifter over til at bruge dette $\mathrm{i}$ dagligtale. Først når der er tale om en større sproglig distance, volder et sprogskifte besvær og tager lengere tid, jvf. italienere og polakker i U.S.A., tyskere i Øst- og Sydøsteuropa og i Brasilien.

Ud fra det ovenfor navnte om udbredelsen af "den musikalske dobbeltakcent" må det stå klart, at anglernes - ligesom også jydernes (og hvis man skal tro Prokopios ligeledes frisernes) - bidrag til indvandringen til Britannien har været beskedent i forhold til sachsernes. De gamle kongeriger, Wessex, Sussex, Essex, havde navn efter sachserne på fastlandet. Det var derfor også det vestgermanske old-saxiske sprog, der var det fremherskende blandt Britanniens landnamsmænd fra fastlandet.

Hvis denne teori holder stik, må én gang for alle den myte aflives, at "anglerne«, forstået som »alle anglerne«, var udvandret til Britannien omkring år 450. Et helt folk udvandrer ikke, selv om ændrede levevilkår tvinger en stor del af en befolkning til at forlade sin hjemstavn. Kun som følge af en statsmagts indgriben - som f.eks. romerkejseren Hadrians "Endlösung der Judenfrage« år 135 eller den moderne tids tvangsflytninger af grækere og tyrkere og fordrivelsen af tyskerne fra deres øst-områder - bliver noget sådant tilfældet. 
Det sproglige problem: 1 . anglernes nordgermanske (nordiske) sprog i det gamle Angler-rige mellem Olmersdiget og Ejderen og fra Langeland til Sydslesvigs vestkyst og 2 . anglernes vestgermanske sprog i Britannien, løses følgelig nemmest og lettest ved hjælp af teorien om, at Britanniens anglere hurtigt har lært sig at bruge den derværende saxiske befolknings vestgermanske (»oldnedertyske«) sprog.

Nøjagtig den samme sproglige udvikling kom også de jyske indvandrere ud for. Beda omtaler jo side om side wtre tapre germanske stammer, saxerne, anglerne og jyderne . Alligevel er alle enige om, at hovedparten af jyderne lever $\mathrm{i}$ bedste velgående $\mathrm{i}$ Jylland (ligesom det store sachser-folk endnu bebor hele det nordvest-tyske område, Holsten, Hamburg, Niedersachsen, Bremen etc.).

Ud fra disse kendsgerninger må det være berettiget at anse »den musikalske dobbeltakcent" som et vidnesbyrd om, at også anglernes efterkommere stadig lever i deres gamle hjemstavn, selv om hovedparten af dem syd for Flensborg fjord siden begivenhederne i senmiddelalderen har skiftet sprog, ejendommeligt nok også til vestgermansk, nemlig til plattysk (middelalderens nedertysk, "mittelniedersächsisch «). ${ }^{19}$

Og ved vestkysten har anglerne måttet afgive plads til de vestgermansktalende frisere, der menes at være indflyttet á to gange, ø-friserne omkring år 500 og strand-friserne omkring år 1000. Stednavne vidner om, at der også i de nordfrisiske egne oprindeligt har boet nordisktalende folk.

\section{$\mathrm{Da}$ anglerne blev verdenskendte!}

Næsten 200 år gik hen efter romernes rømning af provinsen Britannia og efter indvandringen fra fastlandet - som nævnt overvejende af sachsere, men med tilslutning også af anglere, jyder og antagelig også af frisere -, før det lykkedes at skabe et vist fællesskab mellem de forskellige folkeslag. Det store skel bestod ikke i første række af de små kongeriger, der var dannet, men først og fremmest af de religiøse tilstande. Det var religionen, der udgjorde det egentlige kulturskel mellem de forskellige indbyggere.

De germanske indvandrere var hedninger, mens den tilbageblevne keltoromanske befolkning (ligesom alle indbyggere i Romerriget efter år 313) havde antaget kristendommen. Uden for den romerske provins var også kelterne $\mathrm{i}$ Wales, Skotland og Irland blevet kristne, men under de urolige år i 400-tallet var forbindelsen til Rom og dermed til pavestolen blevet afbrudt. Deres kirke blev derfor kaldt den iro-scotiske kirke.

Under pave Gregor den Store (590-604) lykkedes det imidlertid pavestolen 
at genoprette forbindelsen til den tidligere romerprovins, idet saxerne og de andre indvandrere fra fastlandet i 597 antog kristendommen i dens romerskkatolske skikkelse. Ifølge Beda skal Gregor være blevet så begejstret over sine nye proselytter, at han $i$ et brev - måske ud fra et kendskab til Tacitus udtalte, at beboerne ikke skulle kaldes "anglii (anglere), men »angli« (engle). ${ }^{20}$

Dermed var bolden givet op for en kraftig fremhævelse af anglerne på bekostning af de andre germanske indvandrer-folk. Sin kirkehistorie kaldte Beda "Historia Ecclesiastica Gentis Anglorum«, d.v.s. angler-folkets kirkehistorie. Den stammer fra 731, og kort tid efter førte kong Offa af Mercia (756-796) i sine breve titlen "rex Anglorum«, og som sådan forhandlede han med Karl den Store (768-814).

Også Alfred the Great (871-899), hvem det i 878 lykkedes at få danskerne til at nøjes med Danelagen (the Danelaw) og i 885 at erobre London, overtog angler-navnet som fællesbetegnelse for sit rige og dets indbyggere. Skønt han selv var begyndt som konge af Wessex og havde dette områdes saxiske sprog som sit modersmål, blev begrebet "englisc sprek “ (det engelske sprog) anvendt som fast terminus, og hans magtområde fik en ny identitet som "Engla Lond «, England. ${ }^{21}$

I modsætning til engle-navnet "angli« var der ingen grund til at være stolt af saxer-navnet, for helt frem til år 804 kæmpede de hedenske sachsere på fastlandet for at modstå Karl den Stores kristne Franker-rige. Endvidere kunne saxer-navnet måske endda føre til et krav om et herredømme også over saxerne i den forhenværende romerprovins Britannia. Frankerne havde jo på deres egen facon genrejst det gamle Romer-rige!

Så vidt kom det nu ikke. Anglia blev fremover det latinske navn for England. Provinsen East Anglia betyder derfor ikke »Øst-Angel«, men i overensstemmelse med geografien "det østlige England«.

De anførte eksempler fra Beda og fra kongerne Offa og Alfred viser, at både kirke og stat kunne have fordel af at bruge angler-navnet. Efterhånden blev det dog i erkendelse af saxernes rent faktiske dominans mere almindeligt at sige angel-saxerne og angel-saxisk (»anglo-saxon«).

Inden for den ikke-latinske litteratur fra oldtidens England findes der intetsomhelst, der er affattet på et særligt angelsk sprog. Som Bjerrum fremhævede: det lader sig ikke gøre wat konstituere et nært slægtskab mellem nordisk og den angelske afdeling af oldengelsk; på alle væsentlige punkter ... er anglernes og saxernes sprog fuldstændig ens«. Hvis han havde tænkt på muligheden af et sprogskifte, kunne han med fuld ret have sagt: det af anglerne i England talte nordiske sprog er gået tabt. Men da angler-navnet nu engang var blevet op-prioriteret, foretrak man den kunstige term wangel-saxisk «. 


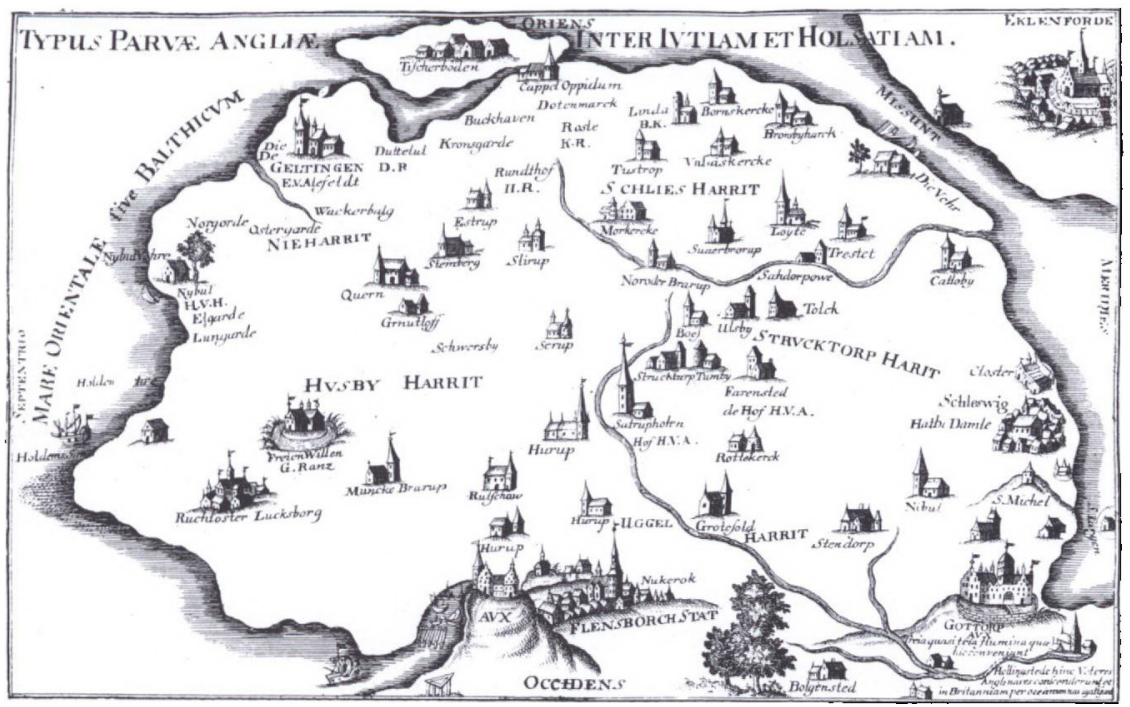

Den store humanist Heinrich Rantzau var optaget af Anglernes glorvardige historie. I hans vark "Cimbrica Chersonesi Descriptio Novaw indgik dette kort over landskabet Angel. Udg. E.J. Westphalen: Monumenta Inedita Rerum Germanicarum I, 1734.

\section{Anglerne i sagnhistorien}

Ingen har beskæftiget sig med angler-problemet uden at have henledt opmærksomheden på den oldengelske ("angel-saxiske«) sagnhistorie. Især har digterværkerne Widsith og Beowulf påkaldt sig interesse. Begge findes overleveret fra ca. år 1000, men dele af dem må være langt ældre, måske fra 600-årene. Indholdet er $\mathrm{i}$ begge tilfælde sagnhistoriske skildringer af begivenheder og forhold fra ikke blot det britiske, men også fra det danske og nordiske område, ja langt ud i Europa, og der er selvsagt derved åbnet en vid mark for allehånde spekulationer over, hvor meget af dette stof der lader sig udmønte som egentlig historie. Man har bl.a. påpeget, at især Widsith synes orienteret om et Anglerrige. En lokalitet "Fifeldor" sidestilles uden videre med "Egidora«, Ejderen, men $\mathrm{i}$ betragtning af Slesvig-Hedebys merkantile betydning på den tid er det måske slet ikke så markeligt endda.

I forbindelse med de to heltekvads omtale af ættefejder og enkeltmænds stordåd, har man navnlig heftet sig ved Widsiths omtale af Offa som hersker over Angel (Ongle, på latin Anglia): "Modigst var han af alle mænd«; ingen overgik ham i djærvhed, "thi Offa vandt, først af mændene, endnu som dreng det største kongerige«. Det var ham, der »med ét sværd« satte grænsen ved »Fifeldor«. 
Offa fra Mercia blev altså en af de helt store sagnskikkelser, og da beretningen om ham blev kendt af middelalderens danske historieskrivere, Saxo og Svend Aggesen, afgav den stof til fortællingen om Uffe og hans drabelige kamp på en ø i Ejderen mod en sachsisk prins. Navneformen Uffe viser, at sagnet ikke stammer fra en hjemlig tradition, men at det er overtaget udefra, og når det blev brugt, skyldes det, at det for de to historieskrivere var velegnet til at illustrere, at Valdemars-tidens kampe ved Ejderen mod fjenden fra syd ikke var noget nyt for denne tid. Det ligger snublende nært at antage, at der med beskrivelsen af lokaliteten er tænkt på den ø i Ejderen, hvor den holstenske grev Adolf umiddelbart før år 1200 havde anlagt befæstningen Rendsburg. Med det gamle Angler-rige har Uffe og hans fader Vermund intet at bestille. ${ }^{22}$

\section{Afslutning}

Det vil af de her fremsatte betragtninger fremgå, at anglernes plads i historien er blevet vildt overdrevet. Efter den arkæologiske undersøgelse af Olmersdiget kan der ganske vist næppe være tvivl om, at anglerne har haft et særligt rige syd for dette forsvarsværk, og følgelig må det være herfra, at udvandringen til øen Britannien har fundet sted, men af eftertiden har de fået tildelt en rolle, der langt overstiger deres betydning. Selv om det først og fremmest var saxerne, der skabte det nye samfund på øen hinsides Nordsøen, var det anglerne, der takket være, at deres navn »anglii lod sig sidestille med »angli«, fik ry for at være de førende. Med et angel-saxisk ord er det intet mindre end et "scoop«, at de uden egen indsats blev verdenskendte ved at give navn til England og englænderne; om man vil: et af historiens luner!

\section{NOTER OG HENVISNINGER}

1. I min Plattysk i Sønderjylland, 1974, s. 9-11, fulgte jeg Anders Bjerrums opfattelse af anglerproblemet, men siden har jeg andret mening. Den herværende afhandling bygger på en forelæsning, holdt 1982 i »33. Symposium der Arbeitsgemeinschaft für Sachsenforschung« i Slesvig by.

2. Dette var således tilfældet på Karl den Stores tid, se herom H.V. Gregersen: Den danske kongemagt ved vikingetidens begyndelse (Sønderjyske Arbøger 1983, s. 17, samt note 18).

3. Snorre Sturlason: Heimskringla, udg. Johs. V. Jensen \& Hans Kyrre 1948, s. 51, 56 f.

4. I Sønderjyske Stednavne (se Registeret) findes adskillige eksempler på navne, begyndende med Frue- eller Brude-. Desuden skal der henvises til Øster Logum-præsten Peter Kier i Antiqvariske Annaler, I, 1812, s. 328; H.V. Gregersen: Bolderslev i førkristen tid (Sønderjysk Månedsskrift 1951, s. 49-55). 
5. Jvf. f.eks. H.V. Gregersen: Om det kontinuerlige i vor historie (Stambladet, I, 1963, s. 243-248).

6. For Sønderjyllands vedkommende er en sådan pávist ved en pollenundersøgelse af Abkar mose sydvest for Vojens, se Bent Aaby: Mennesket og naturen på Abkær-egnen gennem 6000 år (Sønderjysk Månedsskrift 1986, s. 277-290, spec. s. 284).

7. Bent Sendergaard: Indledende studier over den nordiske stednavnetype lev (löv), 1972; heri: Forholdet mellem de nordiske levnavne og de tyske lebennavne, s. 158-180, med oversigt over den foreliggende litteratur, med registrering af leben-navnene, samt påvisning af bảde sikre og mulige paralleller til danske lev-navne.

8. Bornholm havde ifølge Wulfstans beretning i Kong Alfreds udgivelse af Orosius en egen konge, og Blekinge er måske forst kommet til Danmark på Knud den Stores tid, jvf. Erik Kroman: Det danske Rige i den ældre Vikingetid, 1976, s. 14.

9. H.V. Clausen: Studier over Danmarks Oldtidsbebyggelse (Aarbøger for nordisk Oldkyndighed og Historie, 1916). H.V. Clausens hypotese om en fra Sjalland/Skåne udgående erobring af det vestlige Danmark er siden Johannes Steenstrups kritik (»de dragne Slutninger er uholdbare og vildledende $($ ) alt $\mathrm{i}$ alt blevet negativt modtaget. Jeg mener med urette. Hans hovedtese om danerne som et estfra kommende erobrerfolk, hvis stormænd, næunt i lev-byernes forled, har overtaget jord, kan ikke uden videre afvises.

10. En tværgående palerække i Haderslev fjord, kaldt me Lei« (Leddet), anses for at have været en afspærring af fjorden mod østfra kommende. Den er for nylig blevet dateret til 404 og kan følgelig opfattes som et værn mod de østfra kommende danere.

11. Hans Neumann: Olgerdiget - et bidrag til Danmarks tidligste historie, 1982, hvortil der henvises, hvad de arkæologiske afsnit angår. Den romantiserede navneform »Olgerdige« skyldes den historisk interesserede Uge-præst Nicolaus Nissen (sognepræst 1740-77), der leverede stof fra sit sogn til Erik Pontoppidans Danske Atlas. Retteligt hedder anlægget Olmersdige, hvis forled moldemor« betegner noget meget gammelt, jvf. f.eks. Ribe Oldemoder. Endelsen »-dige« betyder - som også fremhævet af Hans Neumann (s. 8) - både grøft og vold.

12. Desværre fandt Hans Neumann ikke Harvejens passage af Olmersdiget. Den skal søges i nærheden af Tulsbro Bjerg, som i Stednavneudvalgets gengivelse af den stedlige udtale under påvirkning af et narliggende landsbynavn er blevet til "Todsbøl Bjerg« (hos Neumann: "Tødsbøl«), jvf. H.V. Gregersen: Oldtidens og tidlig middelalders Harvej uden om Unehoved (Nordslesvigske Museer, bd. 6, 1979, og Sønderjysk Månedsskrift 1979, s. 439-444, spec. s. 443).

13. Hans Neumann, der i sin bog "Olgerdiget« samstemmende hermed anser det for et gammelt skel mellem angler og jyder, lader jydernes område fra 200-400 svare til det arkæologiske område, der har fået navn efter Over Jerstal (på tysk: Ober Jersdal! Endelsen er -stald), se kort s. 85.

14. Det var sprogmanden, forfatteren og journalisten Nikolaj Andersen (fodt i Svejrup i Felsted sogn), der forst gjorde opmærksom på sin hjemegns særlige sprogtone med afhandlingen $m$ Den musikalske akcent i Østslesvig (Dania 1897).

15. Erik Kroman giorde sig i »Musikalsk Akcent i Dansk«, 1947, til talsmand for, at denne særlige sprogtone skulle skyldes en indvandring fra Sverige. Siden da er tesen om et "svenskevælde $i$ det sydlige Danmark blevet grundigt aflivet, dels m.h.t. stednavne på -by (+personnavn) af Birthe Hjorth Pedersen: Bebyggelsesnavne på -by sammensat med personnavn (1960) og m.h.t. runeindskrifterne og Adam af Bremens tekst af Nils Lund: Svenskevaldet i Hedeby (Aarbøger for Nordisk Oldkyndighed og Historie, 1980, s. 114-125).

16. Se herom: Paul G. Buchloh i: Offa, bd. 37, 1980, s. 361).

17. Jvf. note 6.

18. Denne opfattelse går helt tilbage til Beda og især til kong Alfreds udgivelse af Orosius, hvor det i Ottars beretning hedder: »I disse lande (efter omtalen af Danmark og »Gotland mange øer «) boede anglerne, før de kom herover til dette land«. De sidste ord (»ær hi hider om land coman () tyder på, at der her er tale om et redaktionelt indskud i Ottars beretning.

19. Se herom: H.V. Gregersen: Plattysk i Sønderjylland, 1974; samt oversigtsmæssigt sms.: Slesvig og Holsten indtil 1830, 1981. Når fortyskningen af Sydslesvig tog flere århundreder, skyldes det, at her trængte det fremmede sprog ind på en flertalsbefolknings oprindelige sprogområde. Det er noget helt andet end et indvandrermindretals overtagelse af en flertalsbefolknings sprog. 
20. Se herom: Paul G. Buchloh: Angeln - Regio oder Natio? - Eine philologische Betrachtung (Offa, bd. 37,1980 , s. $360-365$ ).

21. Det kan altsammen minde om, at begreberne "britisk " og "(Stor)Britannien " fik en renæssance, da James I efter Elizabeths død i 1603 blev konge over hele øen.

22. I en fremstilling af Senderjyllands historie hører sagnet om Vermund og Uffe derfor rettelig hjemme under en omtale af Saxos interesse for Sønderjylland, jvf. H.V. Gregersen: Slesvig og Holsten indtil 1830 , s. 107. 